\title{
ANALISIS MISKONSEPSI MAHASISWA CALON GURU KIMIA PADA KONSEP PARTICULATE OF MATTER
}

\author{
Yuli Rahmawati ${ }^{1}$, Tuszie Widhiyanti ${ }^{2}$ dan Alin Mardiah', \\ ${ }^{1}$ Pendidikan Kimia, Fakultas Matematika dan Ilmu Pengetahuan Alam, Universitas Negeri \\ Jakarta, Jalan Rawamangun Muka, Jakarta Timur, 13220, Indonesia \\ ${ }^{2}$ Pendidikan Kimia, Fakultas Pendidikan Matematika dan Ilmu Pengetahuan Alam, \\ Universitas Pendidikan Indonesia, Jalan Dr. Setiabudi No. 229, Bandung 40154, Indonesia \\ *E-mail: yrahmawati@unj.ac.id
}

\begin{abstract}
ABSTRAK
Penelitian ini bertujuan untuk menganalisis miskonsepsi mahasiswa calon guru pada konsep particulate of matter. Metode yang digunakan dalam penelitian ini adalah survei dengan teknik pengumpulan data berupa two tier diagnostic test Particle Theory Diagnostic Instrument (PTDI) yang diadaptasi dari Treagust, Chandrasegaran, Crowley, Yung, Cheong dan Othman serta dikembangkan oleh Widhiyanti, observasi, dan wawancara yang diujikan pada mahasiswa calon guru program studi pendidikan kimia tingkat I sampai IV berjumlah 148 mahasiswa. Hasil penelitian menunjukkan bahwa mahasiswa mengalami miskonsepsi pada 10 butir soal dari 11 soal yang diberikan pada instrumen two tier diagnostic test. Konsistensi jawaban siswa pada setiap kategori tidak mencapai $10 \%$ dari jumlah jawaban benar, mahasiswa tidak memahami konsep secara mendalam. Hal ini dibuktikan dengan penurunan jumlah jawaban benar (pada tier 1) dan alasan benar (pada tier 2) dengan persentase lebih dari 10\%. Dengan demikian, perlu dilakukan pendalaman materi particulate of mater pada mahasiswa calon guru kimia untuk mengatasi miskonsepsi yang terjadi.
\end{abstract}

Kata kunci: miskonsepsi, particulate of matter, particle theory diagnostic instrument (PTDI), two-tier diagnostic test

\begin{abstract}
The aim of the study was to analyze the pre-service chemistry teachers' misconceptions in the particulate of matter. This study was a survey with data collection of two-tier diagnostic test of Particle Theory Diagnostic Instruments (PTDI) was adapted from Treagust, Chandrasegaran, Crowley, Yung, Cheong and Othman and also developed by Widhiyanti, observations, and interviews. The results showed that students had misconceptions in 10 items from 11 questions given. The consistency of students' answers in each category did not reach 10\% of the number of correct answers, students don't have deep understanding of the concepts. There was the decrease in the number of correct answers (in tier 1) and the correct reason (in tier 2) with the percentage of more than $10 \%$. Thus, it is important for the pre-service teachers to understand the concept of particulate of matter on order to overcome misconceptions.
\end{abstract}

Keywords: misconceptions, particulate of matter, particle theory diagnostic instrument (PTDI, two-tier diagnostic test

DOI: http://doi.org/10.15575/jtk.v4i2.4824 


\section{PENDAHULUAN}

Kimia merupakan disiplin ilmu yang memiliki banyak konsep dan topik yang bersifat abstrak sehingga umumnya mahasiswa kesulitan dalam menghubungkan ilmu kimia yang abstrak dengan keadaan konkret yang riil (Osborne \& Dillon, 2008; Mahdi, 2014; Woldeamanuel et al., 2014). Sehingga dalam pembelajaran, ilmu kimia direpresentasikan dalam tiga level representasi, yaitu makroskopis, sub mikroskopis, dan simbolik (Chandrasegaran et al., 2008).

Berdasarkan kurikulum 2013 yang berlaku di Indonesia saat ini, proses pembelajaran diselenggarakan dengan berpusat pada siswa sehingga siswa dapat berpartisipasi aktif dan dapat membangun pemahamannya sendiri tentang suatu konsep. Akan tetapi, ketika siswa mencoba membangun sendiri pemahamannya, terdapat kemungkinan terjadinya miskonsepsi. Miskonsepsi adalah fenomena terjadinya perbedaan pemahaman konsep siswa dengan konsep yang sebenarnya (Demircioglu, 2005). Miskonsepsi pada siswa dapat disebabkan oleh berbagai faktor, seperti pengajaran guru, buku teks, dan metode pembelajaran yang digunakan (Barke et al., 2009). Penelitian tentang miskonsepsi telah banyak dikembangkan di Indonesia, seperti profil miskonsepsi siswa pada topik kesetimbangan kimia (Satriana dkk., 2018), analisis laboratory jargon dan miskonsepsi dalam materi asam basa (Hadinugrahaningsih dkk., 2018), dan analisis miskonsepsi siswa pada konsep ikatan ionik dan kovalen dengan menggunakan tes diagnostik three tier (Prodjosantoso dkk., 2019).

Selain pada siswa, kesalahpahaman konsep dimungkinkan juga terjadi pada mahasiswa calon guru. Permasalahan pemahaman terhadap konsep-konsep mahasiswa calon guru sangat penting, karena kesalahan konsep yang dimiliki calon guru akan berdampak signifikan terhadap kompetensinya sebagai seorang guru. Miskonsepsi calon guru ini terkait dengan konsep dasar kimia yang dikaji dalam tiga sudut pandang representasi kimia. Sehingga pada penelitian ini akan dikaji miskonsepsi mahasiswa sebagai pondasi awal penelitian berkelanjutan yang terfokus pada kompetensi calon guru.

Salah satu cara untuk menganalisis miskonsepsi calon guru adalah dengan tes diagnostik baik berupa pilihan ganda ataupun two atau three tier diagnostic test, konsep map, dan wawancara. Pada penelitian ini digunakan two-tier diagnostic test pada konsep particulate of matter yang dikembangkan oleh Widhiyanti (2016). Pada awalnya tes ini diawali oleh penelitian Treagust et al. (2010) mengenai kinetic theory of particle yang merupakan konsep dasar dalam memahami materi. Jenis tes diagnostik ini ditemukan oleh Tamir (1971) dan dikembangkan oleh Peterson \& Treagust (1986). Two-tier diagnostic test adalah tes diagnostik yang terdiri dari pilihan jawaban di tingkat pertama dan juga pilihan alasan untuk jawaban tingkat pertama di lapis kedua. Dengan desain ini item, tes diagnostik two-tier memungkinkan pendidik untuk mengidentifikasi konsepsi alternatif siswa tentang konsep tertentu (Treagust, 1988).

Kimia pada prinsipnya adalah disiplin ilmu yang mempelajari materi, perubahannya, dan energi (Chang, 2003). Sehingga konsep materi merupakan salah satu konsep dasar yang harus dipahami oleh calon guru kimia. Pemahaman pada konsep ini akan berdampak pada pemahaman calon guru pada konsep selanjutnya. Sehingga penelitian ini akan memberikan gambaran permasalahan pemahaman konsep calon guru kimia yang merupakan refleksi proses pembelajaran yang dilakukan. 


\section{METODE PENELITIAN}

Metodologi penelitian yang digunakan adalah survei pada pemahaman calon guru terhadap konsep partikel materi. Penelitian melibatkan 148 mahasiswa calon guru tingkat I sampai IV dengan masing-masing berjumlah tingkat I (16), tingkat II (24), tingkat III (35) dan tingkat IV (73). Penelitian menggunakan instrumen two tier diagnostic test dari Particle Theory Diagnostic Instrument (PTDI) digunakan sebagai gambaran umum miskonsepsi mahasiswa calon guru. Instrumen diadaptasi dari Treagust et al. (2010) dan dikembangkan oleh Widhiyanti (2016). Soal yang berjumlah sepuluh pertanyaan yang terdiri dari tiga konsep utama yaitu jarak intermolekuler pada fasa padat, cairan dan gas (nomor soal 3, 4, 5 dan 11), pengaruh gaya intermolekul terhadap perubahan fasa (nomor soal 8, 9 dan 10), dan difusi dalam cairan dan gas (nomor soal 1, 2, 6 dan 7). Analisis lebih lanjut menggunakan data kualitatif melalui wawancara pada mahasiswa yang dipilih untuk menjelaskan gambaran umum miskonsepsi mahasiswa calon guru.

\section{HASIL DAN PEMBAHASAN}

Pemahaman konsep oleh mahasiswa calon guru merupakan aspek yang penting dalam memenuhi kompetensinya sebagai guru. Namun, beberapa penelitian menunjukkan bahwa banyak siswa yang memasuki tahapan baru dalam pendidikan telah memiliki pemahaman konsep dari pendidikan sebelumnya tetapi tidak sesuai dengan konsep yang sebenarnya (Duit et al., 2008; Damanhuri et al., 2016). Ketidaksesuaian pemahaman konsep dengan konsep yang sebenarnya disebut dengan miskonsepsi (Demircioglu, 2005).

Mahasiswa calon guru seharusnya tidak lagi memiliki miskonsepsi. Hal ini dikarenakan kesalahan konsep pada siswa dapat berasal dari guru yang memiliki kesalahpahaman terhadap suatu konsep (Calik \& Ayas, 2005). Miskonsepsi pada berbagai konsep kimia kerap terjadi, salah satunya adalah konsep sifat partikulat materi (Kapici \& Akcay, 2016; Soeharto dkk., 2019). Sehingga, penelitian ini berfokus pada analisis miskonsepsi mahasiswa calon guru dari berbagai tingkat angkatan pada konsep particulate of matter yang dibagi ke dalam tiga ranah yaitu: (1) jarak intermolekular zat padat, cair, dan gas, (2) pengaruh kekuatan molekul akibat adanya perubahan keadaan, (3) difusi cairan dan gas.

Hasil penelitian ini diperoleh melalui tanggapan siswa terhadap 11 item pilihan ganda yang dianalisis dan diklasifikasikan berdasarkan tiga kategori konsep utama pada masing-masing angkatan, yakni angkatan I sampai angkatan IV dianalisis dengan jumlah jawaban benar pada tier 1 dengan persentase tiap angkatan pada setiap butir, persentase jawaban benar pada tier 1 disertai alasan pada tier 2 untuk setiap kategori konsep, kategori konsep dibagi tiga berdasarkan pembagian konsep yang terdapat pada butir soal yaitu: (1) jarak intermolekular zat padat, cair, dan gas, (2) pengaruh kekuatan molekul akibat adanya perubahan keadaan, (3) difusi cairan dan gas. Analisis kesesuaian dan konsistensi jawaban mahasiswa juga dialkukan untuk mengetahui sejauh mana pemahaman konsep mahasiswa. Hasil rata-rata keseluruhan untuk setiap item ditunjukkan pada Tabel 1. Selain itu, analisis dilakukan untuk membandingkan konsistensi jawaban terkait pemahaman konsep mahasiswa dalam tiga kategori konsep yang ditunjukkan dengan tanggapan atau alasan mereka yang disesuaikan terhadap item pilihan ganda yang dipilih. Hasil analisis dirangkum dalam Tabel 1.

\subsection{Kategori Konsep 1}

Kategori konsep 1 terdiri atas item soal nomor 3, 4, 5, dan 11. Berdasarkan hasil yang 
diperoleh, mahasiswa untuk setiap angkatan memiliki jumlah jawaban benar yang hampir merata dengan persentase 50\%. Mahasiswa angkatan IV memiliki jumlah total jawaban benar terbanyak dengan persentase sebesar
$59,24 \%$, sedangkan perolehan persentase terendah adalah angkatan I dengan persentase 56,25\%. Hal ini menunjukkan bahwa tidak ada perbedaan yang signifikan untuk jumlah jawaban benar setiap angkatan.

Tabel 1. Persentase Mahasiswa Calon Guru yang Menjawab Benar di Tier Pertama pada Tiga Kategori Konsep

\begin{tabular}{|c|c|c|c|c|c|c|c|}
\hline \multirow{2}{*}{ No } & \multirow{2}{*}{ Kategori Konsep } & \multirow{2}{*}{ No. Soal } & \multicolumn{4}{|c|}{$\begin{array}{c}\text { Mahasiswa Calon Guru } \\
\text { Angkatan }\end{array}$} & \multirow{2}{*}{$\begin{array}{l}\text { Jumlah } \\
N=148\end{array}$} \\
\hline & & & $\begin{array}{c}\mathrm{I} \\
\mathrm{N}=16\end{array}$ & $\begin{array}{c}\text { II } \\
N=24\end{array}$ & $\begin{array}{c}\text { III } \\
N=35\end{array}$ & $\begin{array}{c}\text { IV } \\
N=73\end{array}$ & \\
\hline \multirow{5}{*}{1} & \multirow{5}{*}{$\begin{array}{l}\text { Jarak intermolekuler dalam padatan, } \\
\text { cairan dan gas }\end{array}$} & 3 & 87.5 & 62.5 & 77.14 & 79.45 & 76.65 \\
\hline & & 4 & 62.5 & 66.67 & 74.28 & 69.86 & 68.33 \\
\hline & & 5 & 62.5 & 75 & 71.43 & 80.82 & 72.44 \\
\hline & & 11 & 12.5 & 25 & 0 & 6.85 & 11.09 \\
\hline & & Rata-rata & 56.25 & 57.29 & 55.71 & 59.25 & 57.12 \\
\hline \multirow{4}{*}{2} & \multirow{4}{*}{$\begin{array}{l}\text { Perubahan gaya intermolekul terhadap } \\
\text { perubahan fasa }\end{array}$} & 8 & 50 & 62.5 & 48.57 & 67.12 & 57.05 \\
\hline & & 9 & 93.75 & 87.5 & 91.43 & 76.71 & 87.35 \\
\hline & & 10 & 62.5 & 70.83 & 94.29 & 95.89 & 80.88 \\
\hline & & Rata-Rata & 68.75 & 73.61 & 78.09 & 79.91 & 75.09 \\
\hline \multirow{5}{*}{3} & \multirow{5}{*}{ Difusi dalamcairan dangas } & 1 & 81.25 & 87.5 & 91.43 & 84.93 & 86.28 \\
\hline & & 2 & 68.75 & 37.5 & 45.71 & 68.49 & 55.12 \\
\hline & & 6 & 62.5 & 70.83 & 57.14 & 71.23 & 65.42 \\
\hline & & 7 & 100 & 95.83 & 100 & 93.15 & 97.25 \\
\hline & & Rata-rata & 78.12 & 72.91 & 73.57 & 79.45 & 76.02 \\
\hline
\end{tabular}

\subsection{Kategori Konsep 2}

Kategori konsep 2 terdiri atas item soal nomor 8, 9, dan 10. Jawaban mahasiswa dari keempat angkatan tidak menunjukkan perbedaan hasil yang signifikan untuk setiap angkatan. Perolehan persentase jawaban siswa untuk seluruh angkatan berada di bawah 80\%, dengan persentase yang tidak jauh berbeda untuk setiap angkatan. Jawaban tertinggi diperoleh oleh mahasiswa angkatan ke IV dengan persentase sebanyak 79,9\%. Ada perbedaan yang signifikan antara mahasiswa angkatan I dan angkatan IV, dimana mahasiswa angkatan I memiliki jumlah jawaban benar dengan persentase 68,75\%.

\subsection{Kategori Konsep 3}

Kategori konsep 3 terdiri dari item soal nomor 1, 2, 6, dan 7. Pada kategori ini tidak ada perbedaan signifikan pada keempat angkatan.
Mahasiswa memiliki konsistensi jawaban rata dengan persentase $70 \%$. Persentase jawaban benar terbanyak terdapat pada angkatan IV dengan persentase $79,45 \%$, sedangkan persentase terendah diperoleh angkatan II dengan $72,9 \%$. Hasil yang diperoleh untuk setiap angkatan merata dan tidak ada perbedaan yang signifikan.

Berdasarkan hasil di atas, hal ini menunjukkan bahwa kemampuan mahasiswa dalam memilih jawaban benar cukup baik, terbukti persentase rata-rata yang diperoleh diatas $50 \%$, dimana rata-rata nilai peresentase terbesar mencapai $79,9 \%$.

\subsection{Konsistensi Pemahaman Siswa terhadap Konsep Partikel}

Seperti disebutkan sebelumnya, bahwa nomor soal yang digunakan untuk mengetahui Jurnal Tadris Kimiya 4, 2 (Desember 2019): 121-135

This is an open access article under CC-BY-SA license (https://creativecommons.org/licenses/by-sa/4.0/) 
pemahaman siswa terhadap kategori konsep 1 yakni jarak intermolekuler dalam padatan, cairan dan gas (nomor soal 3, 4, 5 dan 11), perubahan gaya intermolekul terhadap perubahan fasa (nomor soal 8,9 dan 10) dan difusi dalam cairan dan gas (nomor 1, 2, 6 dan 7). Masing-masing kelompok item dianalisis untuk mengevaluasi konsistensi siswa pada pemahaman konsep yang terlibat dalam tiga kategori konsep yang sama sebagaimana diperlihatkan pada Tabel 2.

\subsection{Konsistensi Pemahaman Siswa terhadap Jarak Intermolekuler pada Perubahan Fasa Padat, Cair dan Gas}

Nomor soal 3, 4, 5, dan 11 menganalisis pengertian jarak intermolekul dalam padatan, cairan dan gas. Analisis menunjukkan persentase dan jumlah dari masing-masing sampel yang menjawab dengan benar pada pilihan yang diberikan. Hasil analisis data menunjukkan bahwa hanya siswa angkatan IV yang memiliki jawaban konsisten pada keempat butir soal dengan persentase 1,37\%, selain itumahasiswa angkatan I, II, dan III tidak memiliki konsistensi jawaban pada kategori ini, hal ini dibuktikan dengan proporsi jawaban $0 \%$.

\subsection{Konsistensi Pemahaman Siswa terhadap Pengaruh Gaya terhadap Perubahan Fasa}

Nomor soal 8, 9 dan 10 digunakan untuk mengetahui pemahaman siswa terhadap pengaruh gaya terhadap perubahan fasa. Dalam hal ini, 13 mahasiswa (sekitar 7,56\% dari total sampel), yang menjawab ketiga nomor soal itu dengan benar, serta konsisten dalam pemahaman mereka dari pengaruh gaya terhadap perubahan fasa (lihat Tabel 2). Persentase yang tinggi diperoleh dari mahasiswa angkatan I (6,25\%) yang menjawab keempat soal tersebut dengan benar yang menunjukkan konsistensi terbesar dalam pemahaman mereka tentang difusi konsep
Mahasiswa lebih konsisten dalam pemahaman mereka tentang pengaruh gaya intermolekul pada perubahan fasa dalam konteks yang berbeda (6,25-9,59\%). Kecuali untuk mahasiswa angkatan II, tidak ada mahasiswa yang menjawab dengan konsisten (0\%), mahasiswa dengan konsistensi jawaban tertinggi adalah mahasiswa angkatan IV.

\subsection{Konsistensi Pemahaman Siswa terhadap Pengaruh Gaya terhadap Perubahan Fasa}

Nomor soal 8, 9 dan 10 digunakan untuk mengetahui pemahaman siswa terhadap pengaruh gaya terhadap perubahan fasa. Dalam hal ini, 13 mahasiswa (sekitar 7,56\% dari total sampel), yang menjawab ketiga nomor soal itu dengan benar, serta konsisten dalam pemahaman mereka dari pengaruh gaya terhadap perubahan fasa (lihat Tabel 2). Mahasiswa lebih konsisten dalam pemahaman mereka tentang pengaruh gaya intermolekul pada perubahan fasa dalam konteks yang berbeda (6,25-9,59\%). Kecuali untuk mahasiswa angkatan II, tidak ada mahasiswa yang menjawab dengan konsisten (0\%), mahasiswa dengan konsistensi jawaban tertinggi adalah mahasiswa angkatan IV.

\subsection{Konsistensi Pemahaman Siswa tentang Difusi Cair dan Cairan Gas dalam Persyaratan Sifat Partikulat Materi}

Nomor soal 1, 2, 6, dan 7 melibatkan difusi dalam cairan dan gas. 2 mahasiswa (sekitar $1,16 \%$ dari total sampel) memberikan tanggapan yang benar terhadap keempat soal yang ditampilkan secara konsisten pada pemahaman difusi dalam cairan dan gas terkait teori partikel kinetik (lihat Tabel 2).

dalam konteks yang berbeda. Sedangkan tidak ada mahasiswa yang menjawab dengan konsisten pada angkatan II dan angkatan III. 


\subsection{Alasan Mahasiswa terhadap Tiga Kategori Konsep}

Alasan mahasiswa terhadap tiga kategori konsep yang dianalaisis diperlihatkan pada Tabel 3. Hasil ini merangkum persentase siswa terhadap 11 soal pilihan ganda. Pemahaman konsep di kalangan mahasiswa terbukti kurang tepat terhadap pilihan yang mereka berikan. Sebagian besar mahasiswa memberikan jawaban benar pada tier pertama seperti yang diperlihatkan pada Tabel 1 dengan proporsi persentase yang cukup tinggi, namun sebagian besar mahasiswa memberikan alasan yang kurang tepat. Dalam hal ini terjadi penurunan yang cukup signifikan dengan hasil pada tier 1 dan hasil yang disertai alasan pada tier ke 2. Berikut ini pada Tabel 2 disajikan data jawaban mahasiswa pada pilihan tier pertama dan disertai alasan atau pernyataan yang benar pada setiap item.

Tabel 2. Persentase Siswa yang Menjawab dengan Benar pada Tiga Kategori Konsep Secara Konsisten

\begin{tabular}{|c|c|c|c|c|c|c|}
\hline \multirow[b]{2}{*}{ No } & \multirow[b]{2}{*}{ Kategori Konseptual } & \multicolumn{4}{|c|}{ Mahasiswa Angkatan Ke- } & \multirow{2}{*}{$\begin{array}{c}\text { Jumlah } \\
\text { Keseluruhan } \\
\text { N=148 }\end{array}$} \\
\hline & & $\begin{array}{l}I \\
N=16\end{array}$ & $\begin{array}{c}\text { II } \\
N=24\end{array}$ & $\underset{N=35}{I I I}$ & $\begin{array}{l}\text { IV } \\
N=73\end{array}$ & \\
\hline 1 & $\begin{array}{l}\text { Jarak intermolekuler pada fasa padat, cairan } \\
\text { dan gas (nomor soal } 3,4,5 \text { dan } 11 \text { ) }\end{array}$ & $0(0)$ & $0(0)$ & $0(0)$ & $1.37(1)$ & $0.66(1)$ \\
\hline 2 & $\begin{array}{l}\text { Pengaruh gaya intermolekul terhadap } \\
\text { perubahan fasa (nomor soal 8, } 9 \text { dan 10) }\end{array}$ & $6.25(1)$ & $0(0)$ & $5.71(2)$ & $9.59(7)$ & $6.76(10)$ \\
\hline 3 & $\begin{array}{l}\text { Difusi dalam cairan dan gas (nomor soal } 1,2, \\
\qquad 6 \text { dan } 7 \text { ) }\end{array}$ & $6.25(1)$ & $0(0)$ & $0(0)$ & $1.37(1)$ & $1.35(2)$ \\
\hline
\end{tabular}

Berdasarkan data pada Tabel 3 jika dibandingkan dengan frekuensi tanggapan yang benar terhadap 11 nomor soal pada tier pertama, terdapat perbedaan pada seluruh butir jawaban dengan alasan yang diberikan.

Berdasarkan data Tabel 1 dan 3, terdapat perbedaan hasil pada keduanya yang melebihi $30 \%$. Perbedaan besar antara kedua nilai tersebut mengindikasikan bahwa pemahaman mahasiswa tentang teori-teori partikel kinetik terbatas. Keterbatasan pemahaman pada calon guru akan berdampak pada kompetensinya sebagai guru dan dapat menyebabkan miskonsepsi pada siswa. Hal ini dikarenakan miskonsepsi dapat terjadi karena guru yang kurang memahami konsep sehingga pembelajaran menjadi tidak terarah siswa salah dalam menginterpretasikan konsep materi tersebut (Sadler \& Sonnert, 2016).
Pada soal nomor 3 tentang volume jus jeruk tertentu dipindahkan dari kaleng, 86.28\% mahasiswa (Tabel 1) sepakat bahwa volume cairan tidak meningkat atau tetap. Namun hanya $35.81 \%$ menyatakan bahwa jarak antar partikel tidak berubah karena kekuatan tarik antara partikel itu tetap. Selain itu, berdasarkan hasil analisis jawaban yang diberikan oleh mahasiswa terlihat adanya miskonsepsi pada butir soal nomor 3 sebagai berikut:

Menurut saya, volume jus jeruk tersebut saat
dituangkan kedalam gelas lebar belum
tentu sama walaupun tidak ada yang
tumpah. Hal ini dikarenakan jus jeruk masih
ada yang menempel pada dinding kemasan
sehingga volume yang dituangkan belum
tentu sama. (Wawancara mahasiswa, 21
Juni).

Menurut saya, volume jus jeruk tersebut saat dituangkan kedalam gelas lebar belum tentu sama walaupun tidak ada yang tumpah. Hal ini dikarenakan jus jeruk masih ada yang menempel pada dinding kemasan sehingga volume yang dituangkan belum Juni). 
Tabel 3. Persentase Siswa yang Menjawab dengan Alasan yang Benar (Tier Kedua) pada Tiga Kategori Konsep

\begin{tabular}{|c|c|c|c|c|c|c|c|}
\hline \multirow[b]{2}{*}{ No } & \multirow[b]{2}{*}{ Kategori Konsep } & \multirow[b]{2}{*}{ No. Soal } & \multicolumn{4}{|c|}{ Mahasiswa Calon Guru Angkatan Ke- } & \multirow[b]{2}{*}{$\begin{array}{l}\text { Jumlah } \\
N=148\end{array}$} \\
\hline & & & $\begin{array}{c}I \\
N=16 \\
(2013)\end{array}$ & $\begin{array}{c}\text { II } \\
N=24 \\
(2014)\end{array}$ & $\begin{array}{c}\text { III } \\
N=35 \\
(2015)\end{array}$ & $\begin{array}{c}\text { IV } \\
N=73 \\
(2016)\end{array}$ & \\
\hline \multirow{5}{*}{1} & \multirow{5}{*}{$\begin{array}{c}\text { Jarak intermolekuler } \\
\text { pada fasa padat, cairan } \\
\text { dan gas }\end{array}$} & 3 & $81.3(11)$ & $45.8(11)$ & $74.29(26)$ & $71.23(52)$ & $68.92(102)$ \\
\hline & & 4 & $25(4)$ & $37.5(9)$ & $51.43(27)$ & $36.99(27)$ & $39.19(58)$ \\
\hline & & 5 & $12.5(2)$ & $37.5(9)$ & $45.71(16)$ & $42.47(31)$ & $39.19(58)$ \\
\hline & & 11 & $0(0)$ & $12.5(3)$ & $0(0)$ & $1.37(1)$ & $2.7(4)$ \\
\hline & & Rata-rata & 29.7 & 33.32 & 42.85 & 38.01 & 37.5 \\
\hline \multirow{4}{*}{2} & \multirow{4}{*}{$\begin{array}{c}\text { Pengaruh kekuatan gaya } \\
\text { intermolekul terhadap } \\
\text { perubahan keadaan }\end{array}$} & 8 & $25(4)$ & $20.8(5)$ & $22.86(8)$ & $21.92(16)$ & $22.3(33)$ \\
\hline & & 9 & $31.25(5)$ & $58.3(14)$ & $54.29(19)$ & $57.53(42)$ & $54.05(80)$ \\
\hline & & 10 & $25(4)$ & $29.2(7)$ & $37.14(13)$ & $60.27(44)$ & $45.95(68)$ \\
\hline & & Rata-Rata & 27.08 & 36.1 & 38.09 & 46.57 & 40.76 \\
\hline \multirow{5}{*}{3} & \multirow{5}{*}{$\begin{array}{l}\text { Difusi dalam cairan dan } \\
\text { gas }\end{array}$} & 1 & $56.25(9)$ & $45.8(11)$ & $37.14(13)$ & $27.4(20)$ & $35.81(53)$ \\
\hline & & 2 & $31.25(5)$ & $20.8(5)$ & $31.43(11)$ & $38.36(28)$ & $33.11(49)$ \\
\hline & & 6 & $37.5(6)$ & $37.5(9)$ & $14.29(5)$ & 26.03 (19) & 26.35 (39) \\
\hline & & 7 & $100(16)$ & $87.5(21)$ & $97.14(34)$ & $89.04(65)$ & $91.89(136)$ \\
\hline & & Rata-rata & 56.25 & 47.9 & 45 & 45.21 & 46.79 \\
\hline
\end{tabular}

Berdasarkan hasil jawaban mahasiswa diatas, terlihat bahwa mahasiswa mengalami miskonsepsi pada butir soal nomor 10. Hal ini menunjukkan konsistensi dalam pemahaman siswa tentang konsep partikel pada tiga kategori konseptual ditemukan sangat terbatas pada kemampuannya dalam memberikan penjelasan yang dapat diterima secara ilmiah. Mahasiswa cenderung lebih paham akan konsep dasarnya namun ketika diberi pilihan alasan atau pernyataan atas jawabannya mahasiswa tidak dapat menjelaskannya dengan tepat.

\subsection{Konsep Alternatif Mahasiswa Calon Guru}

Dari analisis tanggapan mahasiswa terhadap item pilihan ganda yang diberikan, beberapa konsepsi alternatif diidentifikasi atas dasar jawaban mahasiswa dimana paling sedikit setidaknya $10 \%$ dari jumlah mahasiswa memilih alasan tersebut (lihat Tabel 4). Nilai
$10 \%$ dipilih sebagai nilai minimum yang lebih tinggi untuk dapat menghilangkan alternatif konsepsi mahasiswa (Peterson, Treagust \& Garnett, 1989). Terdapat 10 butir soal dengan konsepsi yang berlainan dengan konsep yang sebenarnya, pada Tabel 4 terlihat bahwa terdapat 18 alternatif konsepsi yang diberikan oleh mahasiswa, data pengetahuan tentang konsepsi alternatif dapat menjadi informasi yang berguna untuknya perencanaan instruksi kelas bagi dosen. Pada item soal nomor 7 tidak terdapat alternatif konsepsi yang diberikan oleh mahasiswa. Hal ini megindikasikan bahwa pada butir soal 7 mahasiswa seluruh mahasiswa memiliki konsep yang benar. Berdasarkan Tabel 5, terlihat bahwa alternatif konsepsi terbanyak terdapat pada butir soal nomor 2 dimana terdapat 3 alternatif konsepsi yang diberikan oleh mahasiswa dalam menjawab, yang artinya jawaban pada butir soal nomor 2 masih bervariasi dan tersebar pada alasan yang berbeda-beda seperti diperlihatkan pada Tabel 4 berikut: 
Tabel 4. Alternatif Konsep yang Dimiliki Mahasiswa Calon Guru Pada Konsep Partikel

\begin{tabular}{|c|c|c|c|c|c|c|}
\hline \multirow[b]{2}{*}{$\begin{array}{l}\text { No. } \\
\text { Soal }\end{array}$} & \multirow[b]{2}{*}{ Alasan/ Pernyataan } & \multicolumn{4}{|c|}{$\begin{array}{c}\text { Mahasiswa Calon Guru } \\
\text { Angkatan Ke- }\end{array}$} & \multirow[b]{2}{*}{$\begin{array}{l}\text { Jumlah } \\
\mathrm{N}=148\end{array}$} \\
\hline & & $\begin{array}{c}\mathrm{I} \\
\mathrm{N}=16 \\
(2013)\end{array}$ & $\begin{array}{c}\text { II } \\
N=24 \\
(2014)\end{array}$ & $\begin{array}{c}\mathrm{III} \\
\mathrm{N}=35 \\
(2015)\end{array}$ & $\begin{array}{c}\text { IV } \\
N=73 \\
(2016)\end{array}$ & \\
\hline \multirow[b]{2}{*}{1} & $\begin{array}{c}\text { Pergerakan partikel asap yang bergerak zigzag, } \\
\text { karena partikel asap berukuran besar }\end{array}$ & 25 & 54.17 & 62.86 & 60.27 & 50.57 \\
\hline & $\begin{array}{c}\text { Partikel asap yang bergerak zigzag diudara } \\
\text { dimana terdapat ruang yang luas di antara } \\
\text { partikel-partikel asap }\end{array}$ & 43.75 & 45.83 & 28.57 & 34.25 & 38.1 \\
\hline \multirow{3}{*}{2} & $\begin{array}{l}\text { Jumlah tumbukan molekul bromin berkurang } \\
\text { ketika tidak ada partikel udara }\end{array}$ & 0 & 50 & 37.1 & 20.55 & 26.92 \\
\hline & $\begin{array}{c}\text { Molekul bromin dalam bejana hampa udara } \\
\text { dapat menempati ruang yang sebelumnya } \\
\text { ditempati oleh partikel udara }\end{array}$ & 31.25 & 20.833 & 2.86 & 10.96 & 16.47 \\
\hline & $\begin{array}{c}\text { Molekul bromin menyebar secara perlahan } \\
\text { dengan pola zigzag yang acak untuk mengisi } \\
\text { seluruh bagian dalam bejana }\end{array}$ & 50 & 4.16 & 5.71 & 16.44 & 19.08 \\
\hline \multirow[b]{2}{*}{3} & $\begin{array}{c}\text { Volume cairan yang dituangkan ke dalam wadah } \\
\text { yang berbeda memiliki volume tetap dan } \\
\text { partikel-partikelnya dapat bergerak dengan } \\
\text { bebas }\end{array}$ & 18.75 & 20.83 & 2.86 & 4.11 & 11.63 \\
\hline & $\begin{array}{l}\text { Volume cairan yang dituangkan ke dalam wadah } \\
\text { yang berbeda memiliki volume tetap dan } \\
\text { sejumlah partikelnya dapat lolos keluar karena } \\
\text { cairan tersebut menguap }\end{array}$ & 6.25 & 25 & 8.57 & 16.44 & 14.06 \\
\hline 4 & $\begin{array}{c}\text { Partikel-partikel gas mudah di tekan untuk } \\
\text { menjadi lebih kecil dari ukuran partikel semula, } \\
\text { sehingga volumenya berkurang ketika volume } \\
\text { dalam wadah dimampatkan }\end{array}$ & 50 & 45.83 & 28.6 & 46.58 & 42.74 \\
\hline 5 & $\begin{array}{l}\text { Partikel-partikel dalam gas bergerak lebih bebas } \\
\text { dibandingkan dengan partikel-partikel dalam zat } \\
\text { cair ketika volume dimampatkan }\end{array}$ & 43.75 & 45.83 & 28.6 & 34.25 & 38.1 \\
\hline \multirow{2}{*}{6} & $\begin{array}{l}\text { Ketika suatu zat warna diteteskan pada larutan, } \\
\text { partikel-partikel zat pewarna mudah melarut di } \\
\text { dalam air }\end{array}$ & 25 & 29.17 & 31.4 & 35.62 & 30.30 \\
\hline & $\begin{array}{c}\text { Ketika suatu zat warna diteteskan pada larutan, } \\
\text { Partikel-partikel zat pewarna yang lebih berat } \\
\text { mengendap di tabung reaksi }\end{array}$ & 31.25 & 25 & 37.1 & 31.51 & 31.22 \\
\hline \multirow[t]{2}{*}{8} & $\begin{array}{c}\text { Perubahan temperature padatan pada es yang } \\
\text { dipanaskan akan mengakibatkan energi yang } \\
\text { diserap digunakan untuk memutuskan ikatan } \\
\text { pada molekul es }\end{array}$ & 18.75 & 25 & 37.1 & 32.88 & 28.44 \\
\hline & $\begin{array}{l}\text { Perubahan temperature padatan pada es yang } \\
\text { dipanaskan akan mengakibatkan energy yang }\end{array}$ & 31.25 & 37.5 & 31.4 & 31.51 & 32.92 \\
\hline
\end{tabular}




\begin{tabular}{|c|c|c|c|c|c|c|}
\hline \multirow{3}{*}{$\begin{array}{l}\text { No. } \\
\text { Soal }\end{array}$} & \multirow[b]{2}{*}{ Alasan/ Pernyataan } & \multicolumn{4}{|c|}{$\begin{array}{l}\text { Mahasiswa Calon Guru } \\
\text { Angkatan Ke- }\end{array}$} & \multirow[b]{2}{*}{$\begin{array}{l}\text { Jumlah } \\
N=148\end{array}$} \\
\hline & & $\begin{array}{c}\mathrm{I} \\
N=16 \\
(2013)\end{array}$ & $\begin{array}{c}\text { II } \\
N=24 \\
(2014)\end{array}$ & $\begin{array}{c}\text { III } \\
N=35 \\
(2015)\end{array}$ & $\begin{array}{c}\text { IV } \\
N=73 \\
(2016)\end{array}$ & \\
\hline & $\begin{array}{l}\text { diserap digunakan untuk meningkatkan energi } \\
\text { kinetik molekul }\end{array}$ & & & & & \\
\hline \multirow{2}{*}{9} & $\begin{array}{c}\text { Perubahan temperatur ketika es dipanaskan } \\
\text { hingga lebih } 100^{\circ} \mathrm{C} \text {, pada saat mencapai titik } \\
\text { didihnya seluruh molekul air langsung menjadi } \\
\text { uap }\end{array}$ & 25 & 12.5 & 11.4 & 8.219 & 14.28 \\
\hline & $\begin{array}{l}\text { Perubahan temperatur ketika es dipanaskan } \\
\text { hingga lebih dari } 100^{\circ} \mathrm{C} \text { karena pergerakan } \\
\text { molekul-molekul air cukup cepat untuk dapat } \\
\text { mengubah seluruh molekulnya menjadi uap }\end{array}$ & 43.75 & 25 & 22.9 & 24.66 & 29.06 \\
\hline \multirow{2}{*}{10} & $\begin{array}{l}\text { Pada saat terjadi perubahan wujud zat, molekul } \\
\mathrm{H}_{2} \mathrm{O} \text { bergerak saling menjauh satu sama lain }\end{array}$ & 50 & 8.33 & 11.4 & 9.58 & 19.83 \\
\hline & $\begin{array}{l}\text { Pada saat terjadi perubahan wujud zat, ikatan } \\
\text { pada molekul-molekul } \mathrm{H}_{2} \mathrm{O} \text { melemah }\end{array}$ & 18.75 & 33.33 & 45.7 & 27.4 & 31.29 \\
\hline \multirow{2}{*}{11} & $\begin{array}{c}\text { Pada saat pencampuran alkohol dengan air, } \\
\text { molekul alkohol terlarut di dalam air sehingga } \\
\text { volume total berkurang }\end{array}$ & 18.75 & 25 & 14.3 & 15.07 & 18.27 \\
\hline & $\begin{array}{l}\text { Pada saat pencampuran alkohol dengan air, } \\
\text { terjadi tumbukan antar molekul yang } \\
\text { menyebabkan sejumlah molekul menguap }\end{array}$ & 50 & 54.16 & 71.4 & 72.6 & 62.04 \\
\hline
\end{tabular}

Secara keseluruhan, melalui analisis jawaban pada instrumen PTDI menunjukkan bahwa pemahaman mahasiswa yang terbatas tentang konsep teori partikel dari keempat angkatan yang terlibat dalam penelitian ini menunjukkan persentase tanggapan yang benar untuk sampel gabungan pada jawaban benar di tier 1 yang berkisar dari 55.11\% (pada butir soal 2) sampai $97.25 \%$ (pada butir soal 7). Akan tetapi, pada jawaban di tier 2 persentase menurun sangat drastis, berkisar dari $22.3 \%$ (pada butir soal 8) sampai 91.89\% (pada butir soal nomor 7 ). 
Mahasiswa pada setiap angkatan memiliki persentase yang terendah pada butir soal nomor 11 dengan persentase jawaban benar pada tier 1 sebanyak 11.09\% dan jawaban benar disertai alasan pada tier 2 hanya sebanyak $2.7 \%$. Selain itu, mahasiswa dari masing-masing angkatan mengalami kesulitan pada nomor soal yang berbedabeda, sehingga nomor soal yang sulit, tidak dapat dikategorikan secara spesifik masalah kesalahan konsep yang dialami oleh angkatan tertentu. Hal ini dikarenakan kesulitan mahasiswa dalam setiap angkatan berbedabeda, namun secara umum seluruh angkatan mengalami kesulitan dalam mengerjakan soal nomor 11. Butir soal nomor 11 juga merupakan soal yang konsisten terjadi miskonsepsi pada mahasiswa. Butir soal 11 berisi tentang konsep jarak intermolekuler pada fasa padat, cair, dan gas yaitu terkait penurunan volume saat volume air dan alkohol yang sama dicampur bersama. Sebanyak 62,04\% mahasiswa dari seluruh angkatan memiliki konsepsi alternatif dengan uraian pernyataan sebagai berikut.

Pada saat pencampuran alkohol dengan air, terjadi tumbukan antar molekul yang menyebabkan sejumlah molekul menguap.

Berdasarkan data yang diperoleh hanya 2.7\% mahasiswa yang menjelaskan bahwa penurunan volume disebabkan oleh partikel yang menempati tempat kosong pada ruang antar molekul. Hasil penelitian menunjukkan bahwa sebagian besar mahasiswa memiliki alternatif konsep dalam menjelaskan fenomena berkurangnya volume larutan campuran alkohol dan air. Hal ini dapat terjadi karena mahasiswa memiliki pemahaman yang terbatas atau tidak memiliki pemahaman konsep yang mendalam tentang teori partikel kinetik khususnya pada ranah jarak intermolekular dalam fasa padatan, cairan, dan gas.
Ketika pemahaman mahasiswa tentang konsep dievaluasi (berdasarkan tanggapan mereka yang benar dalam tier pertama dan tier kedua), nilainya lebih rendah untuk semua nomor soal. Perbedaan yang relatif besar antara kedua nilai tersebut menunjukkan adanya ketidakpahaman konsep (miskonsepsi). Perbedaan untuk soal benar dalam tier pertama dan jawaban yang disertai alasan pada tier kedua, memberikan hasil dengan perbedaan yang signifikan pada setiap nomor soal yakni diatas 10\%. Dalam hal ini, terdapat indikasi bahwa kemungkinan besar mahasiswa telah mengetahui atau menghafal fakta tentang teori partikel kinetik dengan pemahaman yang terbatas, namun tidak dapat mengetahui pemahaman konsepnya secara mendalam. Penelitian ini berbeda dengan penelitian lain yang terfokus pada evaluasi konsistensi siswa dalam memahami tiga ranah konsep yang dikategorikan berdasarkan teori partikel kinetik, yaitu: (1) jarak intermolekuler dalam padatan, cairan dan gas, (2) perubahan fasa karena pengaruh kekuatan intermolekul dan (3) difusi dalam cairan dan gas.

Konsistensi dalam pemahaman mahasiswa terkait dengan tiga kategori konsep dievaluasi dalam konteks yang berbeda menggunakan tiga sampai empat nomor soal. Penggunaan beberapa pilihan alasan jawaban digunakan untuk mengevaluasi tanggapan mahasiswa pada tier pertama. Berdasarkan analisis, mahasiswa tidak terlalu konsisten dalam memahami konsep-konsep kunci tersebut.

Pemahaman yang konsisten tentang jarak intermolekuler keadaan materi zat padat, cair, dan gas ditampilkan oleh $0.66 \%$ mahasiswa (pada Tabel 2), persentase konsistensi jawaban pada pengaruh kekuatan molekul akibat adanya perubahan keadaan sebesar $6.76 \%$, sementara $1.35 \%$ mahasiswa menunjukkan pemahaman yang konsisten tentang difusi dalam cairan dan gas. Persentase yang jauh 
lebih tinggi menunjukkan konsistensi dalam pemahaman mahasiswa tentang pengaruh kekuatan intermolekul terhadap perubahan fasa. Namun, konsistensi terkait pemahaman mahasiswa tentang masing - masing konsep ini lebih jelas terlihat pada alasan di tier kedua. Hanya satu siswa yang menunjukkan pemahaman yang konsisten tentang jarak intermolekuler di tiga fasa (empat nomor soal), dan hanya dua siswa yang memberikan alasan yang konsisten tentang difusi dalam cairan dan gas (empat nomor soal). Sedangkan untuk pengaruh gaya intermolekul terhadap perubahan fasa, 10 mahasiswa $(6.76 \%$ dari total mahasiswa) memberikan tanggapan yang benar dan penjelasan yang dapat diterima untuk ketiga soal yang berkaitan dengan konsep ini.

Berdasarkan hasil penelitian ini, topik sifat partikulat materi selalu menimbulkan masalah bagi mahasiswa terlepas dari lama atau tidaknya pembelajaran kimia yang mereka peroleh. Topik sifat partikulat materi merupakan salah satu topik pembelajaran kimia yang seringkali terdapat miskonsepsi (Kapici \& Akcay, 2016; Soeharto dkk., 2019). Oleh karena itu, perlu untuk meninjau kembali konsep-konsep ini pada tingkatan yang berbeda untuk memperkuat pemahaman konsep mahasiswa dengan menggunakan strategi pembelajaran yang sesuai. Selain itu, yang tidak kalah penting lagi, dosen harus terbiasa dengan cara siswa mengembangkan pemahamannya tentang topik sifat partikulat materi.

Miskonsepsi pada topik particulate of matter sudah terjadi pada siswa SMP dan SMA (Ayas et al., 2010; Stojanovska et al., 2012). Penelitian yang dilakukan oleh Stojanovska et al. (2012) yang menunjukkan bahwa lebih dari 20\% siswa dari semua tingkatan mengalami miskonsepsi mengenai tiga representasi ilmu kimia (makroskopik, sub-mikroskopik, dan simbolik). Hasil dari penelitian tersebut juga menunjukkan bahwa konsep kimia yang salah dalam buku teks yang digunakan dalam pembelajaran kimia merupakan salah satu penyebab miskonsepsi pada siswa. Selain itu, pemahaman yang rendah dan miskonsepsi pada siswa dimungkinkan berasal dari pengetahuan yang tidak konsisten dan hanya menekankan pada sistem hafalan (Salame et al., 2011). Dengan demikian, untuk memfasilitasi pandangan yang lebih koheren dan konsisten, pembelajaran kimia pada tingkat perguruan tinggi perlu dihadapkan pada berbagai pengalaman belajar dalam konteks yang berbeda-beda agar mahasiswa memahami konsep dengan baik.

Mahasiswa juga harus diberi kesempatan untuk melakukan percobaan yang relevan dengan konsep serta memiliki kesempatan untuk mendiskusikan secara berkelompok terkait alasan pada perubahan yang diamati pada partikel (Johnson, 2006). Beberapa dari item tentang materi yang termasuk dalam PTDI dapat dilakukan melalui percobaan oleh mahasiswa sendiri atau ditunjukkan oleh dosen. Selain itu, representasi juga dapat dilakukan menggunakan video animasi. Hal ini sesuai dengan penelitian yang dilakukan oleh Yezierski dan Birk (2006) yang menunjukkan bahwa penggunaan animasi untuk memvisualisasikan representasi mikroskopik dapat meningkatkan pemahaman konseptual siswa. Strategi instruksional lainnya dapat dilakukan termasuk model dan simulasi komputer maupun analogi (Coll et al., 2005; Harrison \& Treagust, 2000; Justi \& Gilbert, 2002). Salah satu strategi yang dapat diterapkan dalam mengurangi miskonsepsi pada topik particulate of matter adalah imagination stretch teaching strategy yang mendukung pemahaman tentang konsepkonsep ilmiah pada tingkat partikel dan memungkinkan mereka untuk dapat menghubungkan sifat mikroskopis 
dengan pengalaman mereka dalam kehidupan sehari-hari (Alamina dan Etokeren, 2018).

Selain itu, dengan pengetahuan tentang konsepsi alternatif yang dimiliki oleh mahasiswa yang berkaitan dengan teori kinetik partikel yang telah diidentifikasi pada penelitian ini, para dosen dapat menguji pemahaman konsep mahasiswa menggunakan berbagai strategi instruksional seperti: konflik kognitif, Predict-ObserveExplain, tanya-jawab, dan diskusi, agar terbentuk pemahaman konsep secara ilmiah. Hasil penelitian ini akan digunakan untuk mengetahui kesesuaian dari nomor soal dalam instrumen dengan alasannya.

Berbagai konsep sains sudah berkembang selama dua dekade (Treagust \& Chandrasegaran, 2007). Instrumen ini berfungsi sebagai alat yang mudah digunakan untuk mengidentifikasi konsepsi preinstruksional mahasiswa tentang konsep kimia, dan pengetahuan yang dapat digunakan oleh dosen untuk memberikan tindakan yang tepat sebagaimana contoh yang disebutkan sebelumnya untuk memperoleh metode pembelajaran yang sesuai agar mahasiswa dapat mengkonstruk pengetahuan konsep secara ilmiah.

Penelitian terkait pendidikan kimia yang membahas tentang moskonsepsi pada berbagai topik-topik kimia, serta beberapa instrumen diagnostik yang telah ada dapat dikembangkan dan diintegrasikan dalam program pendidikan guru, sehingga dapat memfasilitasi peningkatan pemahaman konsep kimia siswa pada proses pembelajaran (Treagust et al., 2003).

\section{KESIMPULAN}

Berdasarkan hasil penelitian dapat disimpulkan bahwa miskonsepsi mahasiswa calon guru kimia terdapat pada semua angkatan. Berdasarkan analisis 11 butir soal yang diberikan pada instrument two-tier diagnostic test pada konsep particulate of matter, soal yang diberikan terfokus pada evaluasi konsistensi siswa dalam memahami tiga ranah konsep yang dikategorikan berdasarkan teori partikel kinetik, yaitu: jarak intermolekuler dalam padatan, cairan dan gas; perubahan fasa karena pengaruh kekuatan intermolekul; dan difusi dalam cairan dan gas. Hasil penelitian menunjukkan terjadi kesalahan konsep pada 10 butir soal dengan adanya alternative pilihan jawaban lain. Hal ini dibuktikan dengan tidak adanya konsistensi jawaban mahasiswa yang mencapai $10 \%$ pada setiap kategori konsep. Konsep jarak intermolekuler zat padat, cair, dan gas, menjadi konsep terendah dimana hanya 1 mahasiswa (0.66\%) dari 148 jumlah mahasiswa yang dapat menjelaskan konsep dengan benar secara konsisten. Selain itu, pada konsep difusi cairan dan gas hanya 2 mahasiswa (1.35\%) yang dapat menjawab secara konsisten, dan terdapat 10 mahasiswa (6.76\%) mahasiswa yang menjawab pengaruh kekuatan molekul akibat adanya perubahan keadaan. Jumlah persentase jawaban siswa yang disertai alasan pada tier 2 mengalami penurunan sebanyak lebih dari $10 \%$ dari jawaban awal siswa pada tier 1 (jawaban tanpa alasan). Miskonsepsi dibangun berdasarkan pemahaman dan pengalaman siswa yang dipengaruhi oleh karakteristik siswa serta lingkungan sekitar siswa. Konsep yang sesuai dan yang tidak sesuai akan berdampak pada kompetensi calon guru kimia. 


\section{DAFTAR PUSTAKA}

Alamina, J. I., \& Etokeren, I. S. (2018). Effectiveness of Imagination Stretch Teaching Strategy in Correcting Misconceptions of Students about Particulate Nature of Matter. Journal of Education, Society and Behavioural Science, 27(1), 1-11.

Ayas, A., Ozmen, H., \& Calik, M. (2010). Students' conceptions of the particulate nature of matter at secondary and tertiary level. International Journal of Science and Mathematics Education, 8, 165-184.

Barke, H. D., Hazari, A., \& Yitbarek, S. (2009). Students' misconceptions and how to overcome them. In Misconceptions in Chemistry (pp. 21-36). Springer, Berlin, Heidelberg.

Çalık, M., \& Ayas, A. (2005). A comparison of level of understanding of grade 8 students and science student teachers related to selected chemistry concepts. Journal of Research in Science Teaching, 42(6), 638-667.

Chandrasegaran, A. L., Treagust, D. F., \& Mocerino, M. (2008). An Evaluation of a Teaching Intervention to Promote Students' Ability to Use Multiple Levels of Representation When Describing and Explaining Chemical Reactions. Research In Science Education, 237-248.

Chang, Raymond. (2003). Kimia Dasar KonsepKonsep Inti Edisi 3. Jakarta: Erlangga.

Coll, R. K., France, B., \& Taylor, I. (2005). The role of models and analogies in science. International Journal of Science Education, 27(2), 183-198.
Demircioglu, G. A. (2005). Conceptual Change Achieved Through A New Teaching Program on Acid and Base. Journal of Chemistry Education Research and Practice, 6(1), 36-51.

Duit, R., Treagust, D. \& Widodo, A. (2008). Teaching science for conceptual change: Theory and practice, In S. Vosniadou (Ed.), International Handbook of Research on Conceptual Change. New York, USA: Routledge.

Hadinugrahaningsih, T., Zahiya, B., Rahmawati, Y., \& Kartika, I. R. (2018). Analisis Laboratory Jargon dan Miskonsepsi dalam Materi Asam Basa. Jurnal Riset Pendidikan Kimia, 8(2), 11-24.

Harrison, A. G., \& Treagust, D. F. (2000). A typology of school science models. International Journal of Science Education, 22(9), 1011-1026.

Johnson, P. (2006). The development of students' understanding of the particle theory and its role in their conception of macroscopic phenomena. In H. Fischler $\&$ C. S. Reiners (Eds.), Die Teilchenstructur der Materie im Physikund Chemieunterricht (The particle structure of materials in physics and chemistry instruction). Berlin: Logos.

Justi, R., \& Gilbert, J. K. (2002). Models and modelling in chemical education (2002). In J. K. Gilbert, Od Jong, R. Justi, D. F. Treagust \& J Hv Driel (Eds.), Chemical education: Towards research-based practice. Dordrecht: Kluwer Academic.

Kapici, H. Ö.\& Akcay, H. (2016). Particulate Nature of Matter Misconceptions Held By Middle and High School Students in 
Turkey. European Journal of Education Studies, 2(8), 43-58.

Mahdi, J. G. (2014). Student Attitudes towards Chemistry: an Examination of Choices and Preferences. American Journal of Educational Research, 2(6), 351-356.

Osborne, J., \& Dillom. J. (2008). Science education in Europe: critical reflection. London: The Nuffield Foundation.

Peterson, R., \& Treagust, D. (1986). Identification Of, Secondary Students'misconceptions Or Covalent Bonding And Structure Concepts Using A Diagnostic Instrument. Research in science education, 16, 40-48.

Peterson, R. F., Treagust, D. F., \& Garnett, P. J. (1989). Development and application of a diagnostic instrument to evaluate grade $11 \& 12$ students' concepts of covalent bonding and structure after a course of instruction. Journal of Research in Science Teaching, 26(4), 301-314.

Prodjosantoso, A. K., Hertina, A. M., \& Irwanto. (2019). The Misconception Diagnosis on Ionic and Covalent Bonds Concepts with Three Tier Diagnostic Test. International Journal of Instruction, 12(1), 1477-1488.

Sadler, P. M. \& Sonnert, G. (2016). Understanding Misconceptions Teaching and Learning in Middle School Physical Science. American Educator, 2632.

Salame, I. I., Sarowar, S., Begum, S., \& Krauss, D. (2011). Students' alternative conceptions about atomic properties and the periodic table. The Chemical Educator, 16, 190-194.
Satriana, T., Yamtianah, S., Ashadi, \& Indriyanti, N.Y. (2018). Student's profile of misconception in chemical equilibrium. Journal of Physics: Conf. Series, 1097 012066.

Soeharto, Csapó, B., Sarimanah, E., Dewi, F. I., \& Sabri, E. (2019). A Review of Students Common Misconceptions in Science and Their Diagnostic Assessment Tools, Jurnal Pendidikan IPA Indonesia, 8(2), 247-266.

Stojanovska, M. I., Šoptrajanov, B. T., \& Petruševski, V. M. (2012). Addressing Misconceptions about the Particulate Nature of Matter among SecondarySchool and High-School Students in the Republic of Macedonia. Creative Education, 3(5), 619-631.

Tamir, P. (1971). An alternative approach to the construction of multiple choice test items. Journal of Biological Education, 5(6), 305-307.

Treagust, D. F. (1988). Development and use of diagnostic tests to evaluate students' misconceptions in science. International journal of science education, 10(2), 159169.

Treagust, D. F., Jacobowitz, R., Gallagher, J. J., \& Parker, J. (2003). Embedded assessment in your teaching. Science Scope, 26(6), 36-39.

Treagust, D. F., \& Chandrasegaran, A. L. (2007). The Taiwan National Science Concept Learning Study in an international perspective. International Journal of Science Education, 29(4), 391-403.

Treagust, D. F., Chandrasegaran, A. L., Crowley, J., Yung, B. H. W., Cheong, I. P. 
A., \& Othman, J. (2010). Evaluating students' understanding of kinetic particle theory concepts relating to the states of matter, changes of states and diffusion: A cross-national study. International Journal of Science and Mathematics Education, 8(1), 141-164.

Widhiyanti, T. (2016). Curriculum Evaluation and Predict-Observe-Explain Implementation: A Case Study on Developing Chemistry Pre-service Teachers' Understanding of Particulate Nature of Matter in Indonesia. Doctoral Disertation, Curtin University.

Woldeamanuel, M. M., Atagana, H., \& Engida, T. (2014). What Makes Chemistry Difficult?. Issues in ASEAN Journal Community Engagement, 31-43.

Yezierski, E. J. \& Birk, J. P. (2006). Misconceptions about the Particulate Nature of Matter Using Animations To Close the Gender Gap. Journal of Chemical Education, 83(6), 954-96. 